\title{
Microsatellite based assessment of genetic distances within Prunus genus
}

Janka BEDÖ - Zsófia KOVÁCS - Kitti TÓTH-LENCSÉS - Erzsébet KISS Anikó VERES

Szent István Univerity, H-2100, Gödöllö, Páter Károly str. 1; E-mail: veres.aniko@mkk.szie.hu

Keywords: microsatellite, SSR, Simple Sequence Repeats, Prunus, genetic distance

\section{Introduction}

Molecular markers - like microsatellites (SSR) - provide objective possibility for estimating genetic diversity. Microsatellite markers are used not only for cultivar identification but also for the verification of synonyms and homonyms (Testolin et al., 2000; Cheng and Huang, 2009; Wünsch, 2009; Bodor et al., 2014).

Our the aim was to determine genetic distances within 5 members of Prunus genus using 6 SSR markers (BPPCT 002, BPPCT030, BPPCT 041, UDP 96 001, UDP 96 005, UCDCH 17) (Cipriani et al., 1999; Dirlewanger et al., 2002; Struss et al., 2003).

\section{Material and methods}

This research was carried out with 51 peach (Prunus persica L.), 15 apricot (Prunus armeniaca L.), 38 sweet cherry (Prunus avium L.), 29 sour cherry (Prunus cerasus) and 37 plum genotypes from National Food Chain Safety Office (Hungary) and from NARIC, Cegléd using the same 6 SSR primer pairs.

The DNA was extracted from leaves using E.Z.N.A OMEGA DNA extraction kit.

The amplified products were separated on $6 \%$ polyacrylamide gel. The precise size of the amplified SSR regions were detected by Cy-5 fluorescently labeled primers and determined by ALFwin Fragment Analyser 1.0 software.

\section{Results and discussion}

The SSR allele sizes in the case of all genotypes are summarized according to the species in Table 1. Out of the 6 Prunus SSRs BPPCT 041 did not amplify any alleles in apricots.

In the case of peach 13 , sweet cherry 12 , sour cherry 21 , apricot 10 and plum 41 polymorphic alleles were observed (Table 1).

In general out of the 6 Prunus microsatellites UDP 96005 was that locus where the highest number of alleles was amplified and BPPCT 030 produced the least.

\section{Conclusions}

Our result showed for instance that peach cultivars can not be discriminated with UCDCH 17 primer pair but as Table 1 demonstrates it was one of the most variable loci in plum genotypes. In general, UDP 96005 locus gave the highest allele number in the analyzed varieties. 
Table 1: Observed allele sizes in base pair on the tested Prunus varieties

\begin{tabular}{|c|c|c|c|c|c|c|}
\hline Varieties & ВРРСТ41 & ВРРСТ 30 & ВРРСТ002 & UDP96-005 & UDP96-001 & $\begin{array}{l}\text { UDC- } \\
\mathrm{CH} 017\end{array}$ \\
\hline peach & 219,221 & $\begin{array}{c}158,170 \\
176\end{array}$ & 229,231 & 156,172 & 121,129 & 138 \\
\hline $\begin{array}{l}\text { sweet } \\
\text { cherry }\end{array}$ & 201 & 140 & 179,183 & $\begin{array}{c}110,118,120 \\
136\end{array}$ & 110,125 & 188,198 \\
\hline $\begin{array}{l}\text { sour } \\
\text { cherry }\end{array}$ & 201,229 & $\begin{array}{c}140,158, \\
162\end{array}$ & $167,179,183$ & $\begin{array}{c}106,110,118 \\
120,136\end{array}$ & $\begin{array}{c}101,115 \\
125\end{array}$ & $\begin{array}{c}178,182, \\
188,198, \\
200\end{array}$ \\
\hline apricot & - & 140,148 & 187,189 & $\begin{array}{c}94,110,120 \\
156\end{array}$ & 110 & 128 \\
\hline plum & $\begin{array}{c}197,201, \\
205,207211, \\
215,219,221\end{array}$ & $130,144,148$ & $\begin{array}{c}177,179,183, \\
187,189,193, \\
207,219\end{array}$ & $\begin{array}{c}94,100,106, \\
110,112,114, \\
136,150,156\end{array}$ & $\begin{array}{c}99,101, \\
113,125,138\end{array}$ & $\begin{array}{l}130,138, \\
140,142, \\
144,152, \\
154,160\end{array}$ \\
\hline
\end{tabular}

Our hypothesis was that with SSR markers we are able to determine the genetic distances regarding these varieties. In the case of BPPCT 030 and UDP 96005 amplifies a $140 \mathrm{bp}$ long and a 110 bp long fragment, respectively in apricot, sweet cherry and sour cherry, thus there could be an ancestral relationship between them.

In conclusion, our results suggest that within the Prunus genus we could be able to determine not only the intervarietal, but the interspecific genetic distances, as well.

\section{Acknowledgement}

The work/publication is supported by the EFOP-3.6.3-VEKOP-16-2017-00008 project. The project is co-financed by the European Union and the European Social Fund.

\section{References}

Bodor, P; Szoke, A; Toth-Lencses, K; Veres, A; Deak, T; Kozma, P ;Bisztray, GD;Kiss, E(2014): Differentiation of grapevine (Vitis vinifera L.) conculta members based on molecular tools, BIOTECHNOLOGY \& BIOTECHNOLOGICAL EQUIPMENT 281 pp. 14-20.,7p

Cheng, Z., Huang, H.(2009): SSR fingerprinting Chinese peach cultivars and landraces (Prunus persica) and analysis of their genetic relationships. Scientia Horticulturae 120 (2):188-193. DOI: https://doi.org/10.1016/j. scienta.2008.10.008

Cipriani, G., Lot, G., Huang, W. G., Marrazzo, M., Peterlunger, E., Testolin, R. (1999): AC/GT and AG/CT microsatellite repeats in peach [Prunus persica $(\mathrm{L})$ Batsch]: isolation, characterisation and cross-species amplification in Prunus. Theoretical and Applied Genetics 99 (1-2):65-72. DOI: 10.1007/s001220051209

Dirlewanger, E., Cosson, P., Tavaud, M., Aranzana, J., Poizat, C., Zanetto, A., Arus, P., Laigret, F. (2002): Development of microsatellite markers in peach [ Prunus persica (L.) Batsch] and their use in genetic diversity analysis in peach and sweet cherry (Prunus avium L.). Theor Appl Genet 105 (1):127-138. DOI: 10.1007/s00122-002-0867-7

Struss, D., Ahmas, R., Southwich,S.M. (2003): Analysis of sweet cherry (Prunus avium L.) cultivars using SSR and AFLP markers. Journal of the American Society for Horticultural Science, 128: 904-909.

Testolin, R., Marrazzo, T., Cipriani, G., Quarta, R., Verde, I., Dettori, M. T., Pancaldi, M., Sansavini, S.(2000): Microsatellite DNA in peach (Prunus persica L. Batsch) and its use in fingerprinting and testing the genetic origin of cultivars. Genome 43 (3):512-520.

Wünsch, A. (2009): Cross-transferable polymorphic SSR loci in Prunus species. Scientia Horticulturae 120 (3):348-352 DOI: $10.1016 /$ j.scienta.2008.11.012 